EL MUHASABA: Jurnal Akuntansi (e-Journal)

Volume 12 , No. 1, Tahun 2021

P ISSN: 2086-1249 ; E ISSN: 2442-8922

\title{
ANTESEDEN KEAHLIAN OPERATOR SISTEM PENGELOLAAN ASET DESA DI KABUPATEN SITUBONDO
}

\author{
Alwan Sri Kustono \\ Universitas Jember, \\ Jl. Kalimantan No. 37 Jember, 68121, Indonesia \\ e-mail:Alwan.s@Unej.ac.id
}

\begin{abstract}
Sistem Pengelolaan Aset Desa (SIPADES) is a village asset administration recording application. This application provides orderly administrative facilities for the village so that the risk of losing assets can be reduced. The purpose of this study is to test and prove various individual aspects that affect operator competence in running SIPADES. The focus of the study is on the internal factors which include anxiety and computer attitudes. Another factor tested was operator training in using SIPADES in the Situbondo District Government. The data used in this study are primary data. The technique of obtaining data using a survey method. The population that is the object of research is all of the operator of the SIPADES application in Situbondo Regency. Four hypotheses were tested using multiple regression. The gender variable was used as the control variable. The results show that all hypotheses can be accepted. The variables of anxiety, attitude, and training have an effect on the operator's competence in operating SIPADES. The implication of the research is that the village government should increase the number of SIPADES operator training. This training can increase competence to run applications.
\end{abstract}

Keywords: anxiety, attitude, competence

\section{Abstrak}

Sistem Pengelolaan Aset Desa merupakan aplikasi pencatatan administrasi aset desa. Aplikasi ini memberikan fasilitas tertib administrasi bagi desa sehingga risiko asset kehilangan dapat direduksi. Tujuan penelitian ini adalah untuk menguji dan membuktikan berbagai aspek individual yang mempengaruhi keahlian operator dalam menggunakan SIPADES. Fokus kajian pada faktor internal operator yang meliputi kecemasan, dan sikap berkomputer. Faktor lain yang diuji adalah pelatihan operator dalam menggunakan SIPADES di Pemerintah Kabupaten Situbondo. Data yang digunakan dalam penelitian ini adalah data primer. Teknik pemerolehan data dengan metode survey. Populasi yang menjadi objek penelitian adalah operator aplikasi SIPADES di Kabupaten Situbondo. Empat hipotesis diuji dengan menggunakan regresi berganda. Variabel Jenis Kelamin dipergunakan sebagai variabel control. Hasil pengujian menunjukkan bahwa seluruh hipotesis dapat diterima. Variabel kecemasan, sikap, dan pelatihan merupakan berpengaruh terhadap keahlian operator menjalankan SIPADES. Implikasi penelitian adalah pemerintah desa seharusnya meningkatkan jumlah pelatihan operator SIPADES. Pelatihan tersebut dapat meningkatkan kompetensi untuk menjalankan aplikasi.

Kata kunci: Kecemasan, sikap, keahlian 
Alwan Sri Kustono: Anteseden Keahlian Operator Sistem Pengelolaan Aset Desa Di Kabupaten Situbondo

\section{PENDAHULUAN}

Teknologi adalah sesuatu yang pasti berubah.Teknologi berkaitan dengan cara manusia hidup dan mengelola alam semesta. Sejak diketemukannya komputer pada tahun 1940an, perkembangan teknologi seakan-akan begitu cepat dan tak terhentikan. Teknologi yang tak henti selalu berkembang adalah teknologi komputer dan digitalisasi. Tahapan pertumbuhan revolusi industry yang bergerak terus sampai pada 4.0 membawa dunia pada otomatisasi, robotik, data cloud, dan integrasi. Banyak sektor yang yang mentransformasi dengan menggunakan sistem informasi sebagai salah satu sarana untuk menjaga kelangsungan hidupnya (Hoque dan Shah, 2018; Kustono dan Valencia, 2017).

Perkembangan komputer tidak hanya terjadi di perusahaan privat. Organisasi sector public pun tidak terlepas dari pengaruh perkembangan sistem informasi (Ilmi, Setyo Liyundira, Rachmawati, Juliasari, dan Habsari, 2020). Penggunaan sistem informasi tidak hanya terjadi di pemerintahan pusat dan daerah, tetapi juga di pemerintahan desa. Di instansi pemerintahan desa, komputer digunakan sebagai sarana dalam menggunakan dan mengoperasikan penatausahaan keuangan desa dan pencatatan asset desa. Pada lima tahun terakhir, penggunaan sistem informasi keuangan desa (SISKEUDES) telah menjadi kebutuhan yang utama. Pada tahun 2020 ini, pengelolaan kekayaan desa juga mulai menggunakan sistem informasi asset desa yang disebut sebagai SIPADES.

Undang-undang No. 6 Tahun 2014 tentang Desa mengharuskan harta kekayaan desa untuk dikelolan secara efektif, transparan dan akuntabel (Irwandi, Andrizal, dan Putra, 2019; Pemdes, 2018; Sutaryo dan Nuwandari, 2016). Pada tahun 2019, Kementerian Dalam Negeri menginisasi penggunaan perangkat lunak untu pengelolaan asset desa yang diberi nama Sistem Pengelolaan Aset Desa Desa (SIPADES). SIPADES merupakan aplikasi pencatatan administrasi aset desa sesuai dengan Peraturan Menteri Dalam Negeri (Permendagri) RI Nomor 01 Tahun 2016 Tentang Pengelolaan Aset Desa. Aplikasi ini memberikan fasilitas tertib administrasi bagi desa mulai dari perencanaan, pengadaan, penatausahaan sampai dengan penyajian laporan.

SIPADES dimaksudkan untuk membantu pemerintah desa dalam menyelenggarakan kegiatan pencatatan kekayaan desa. Penggunaan SIPADES dimaksudkan agar tertib administrasi, sehingga risiko kehilangan dapat direduksi. Kepala desa sebagai penanggung jawab kekayaan desa dapat menggunakannya untuk memantau keberadaan asset. Aset yang tertib administrasi tentunya lebih memenuhi kepastian nilai. Penggunaan asset dapat dimanfaatkan sepenuhnya untuk kesejahteraan masyarakat desa yang bersangkutan.

Sebuah teknologi sistem informasi yang diimplementasikan tentunya menimbulkan permasalahan penerimaan. SIPADES dioperasikan oleh operator 
Alwan Sri Kustono: Anteseden Keahlian Operator Sistem Pengelolaan Aset Desa Di Kabupaten Situbondo desa dengan latar belakang yang berbeda. Operator antar desa tentunya memiliki karakteristik individu yang berbeda. Perbedaan individual tersebut memberikan konsekuensi kinerja yang berbeda pula (Nugraha dan Laksito, 2014).

Dalam penatalaksanaan asset desa, keahlian operator menjalankan aplikasi menjadi faktor penting. Perbedaan karakteristik operator berkaitan erat dengan keahlian yang dibutuhkan. Oleh karena itu, pemerintah desa dan pemerintah kabupaten harus memperhatikan asosiasi perbedaan individual dengan keahlian. (Pujanira dan Taman, 2017; Yuwana dan Kustono, 2017).

Kecemasan didefinisikan sebagai perasaan yang kuat berupa ketakutan dan keprihatinan. Kecemasan dapat berdampak menjadi ketakutan, penghindaran, atau penolakan. Individu yang berbeda dapat merasakan derajat rasa cemas, takut, tertantang, atau sikap dalam menyikapi implementasi sistem informasi baru. (John, 2013; Saade dan Kira, 2009). Kecemasan dapat juga memacu reaksi antisipasi terhadap sesuatu yang menimbulkan kecemasan.

Dalam menghadapi perkembangan teknologi informasi setiap individu memiliki sikap yang berbeda-beda Operator yang memiliki karakteristik pesimis menerima implementasi SIPADES sebagai sesuatu yang tidak menyenangkan sehingga berkonsekuensi pada penghindaran. Individu yang optimis dengan kehadiran aplikasi percaya bahwa aplikasi tersebut membantu dan bermanfaat. Hal itu mendorong minat untuk mempelajari segala hal yang terkait dengan aplikasu dan meningkatkan keahliannya. Operator yang memiliki sifat optimis menerima hal itu sebagai tantangan, sesuatu yang harus dipelajari, dan tertarik untuk menggunakan dalam menyelesaikan pekerjaannya (D Grupe dan Nitschke, 2013; Sasongko, 2014).

Permasalahan yang berkenaan dengan pengelolaan aset desa pada dasarnya sangat beraneka ragam. Beberapa penelitian tentang sistem keuangan desa menemukan bahwa salah satu permasalahan di penggunaan aplikasi di desa adalah rendahnya kualitas SDM (Firmansyah, 2018; Irwandi et al., 2019). Sumber daya manusia di desa memiliki tingkat kecemasan yang berbeda bila dibandingkan dengan yang tinggal diperkotaan. Pemahaman dan penguasaan terhadap system aplikasi dan komputer kurang dikuasai sehingga penguasaan aplikasi belum dapat dilakukan secara maksimal.

Karakteristik individu menjadi sesuatu yang penting dalam implementasi SIPADES. Pemahaman mengenai faktor-faktor tersebut bermanfaat untuk meningkatkan penggunaan SIPADES sebagai aplikasi penatakelolaan asset desa. Operator SIPADES sebagai ujung tombak pengadministrasian harus memiliki kemamuan untuk menggunakan dan menjalankan aplikasi.

Penelitian mengenai SIPADES belum banyak dilakukan karena beberapa daerah baru mulai menerapkan di akhir tahun 2018. Tujuan penelitian ini adalah untuk menguji dan membuktikan berbagai aspek individual yang mempengaruhi keahlian operator dalam menggunakan SIPADES. Fokus kajian 
Alwan Sri Kustono: Anteseden Keahlian Operator Sistem Pengelolaan Aset Desa Di Kabupaten Situbondo pada faktor internal operator yang meliputi kecemasan, dan sikap berkomputer. Faktor lain yang diuji adalah pelatihan operator dalam menggunakan SIPADES di Pemerintah Kabupaten Situbondo. Rumusan masalah penelitian ini adalah apakah kecemasan, sikap, dan pelatihan memiliki pengaruh terhadap keahlian operator SIPADES di Kabupaten Situbondo?

\section{KAJIAN PUSTAKA}

Manusia menjadi pelaku utama dalam implementasi sistem infromasi. Sistem informasi dikembangkan dalam upaya untuk membantu pekerjaan manusia agar dapat dilaksanakan secara efektif, efisien dan ekonomis. Operator adalah seseorang yang memiliki tanggung jawab untuk menjalankan aplikasu berbasis komputer. Orang yang diberi tanggungjawab sebagai operator memerlukan keahlian-keahlian tertentu karena langsung berinteraksi aktif dengan aplikasi.

Keahlian dalam menggunakan komputer adalah kemampuan pengguna dalam hal aplikasi komputer, dan lain aktivitas yang berkaitan dengan penggunaan komputer sebagai alat bantu kerja (Mannila, Nordén, dan Pears, 2018; Mastuti dan Handoyo, 2019). Operator yang optimis menganggap dirinya dirinya mampu untuk melaksanakan suatu tugas. Penerimaan tersebut cenderung memicu kemampuannya dalam menjalankan aplikasi.

Penerimaan sistem informasi tergantung atas (1) teknologi itu sendiri, dan (2) keahlian atau kemampuan individual dalam menggunakan teknologi. Keahlian merupakan faktor pengendali internal yang secara positif dapat mempengaruhi individu. Keahlian dapat membantu mengembangkan pemahaman yang mendalam mengenai aplikasi yang dijalankan. Individu yang memiliki literasi lebih cepat dan lebih fokus sehingga ia tidak mengalami kesulitan pada saat melakukan penggunaannya (Kumar, Sivashanmugam, dan Venkataraman, 2017; LaPlant, 2015; Lee et al., 2017).

Keahlian tentang aplikasi merupakan faktor internal yang dapat mempengaruhi penerimaan sistem informasi baru. Pengetahuan membantu pengguna untuk memberikan tanggapan efektif sehingga mampu membuat keputusan yang lebih tepat. Aplikasi yang dipergunakan diharapkan dapat melakukan tugasnya sesuai dengan yang diinginkan oleh pengguna.

Keahlian menggunakan aplikasi komputer menyebabkan perubahan pada sudut pandan sesorang ketika beriteraksi dan menggunakan dengan aplikasi. Ia akan menjadi pengguna aplikasi komputer untuk menyelesaikan tanggung jawab pekerjaannya secara tepat.

\section{Kecemasan}

Kecemasan adalah pikiran negative. Pikiran ini diwarnai oelh seberapa gelisah dan takut perubahan atau kejadian terjadi. Individual merasa terancam karena perubahan situasi dan kondisi. Kecemasan yang berlebihan meimbulkan keragaman perilaku pertahanan diri. Pertahanan diri tersebut dapat berupa 
Alwan Sri Kustono: Anteseden Keahlian Operator Sistem Pengelolaan Aset Desa Di Kabupaten Situbondo gerak-gerik, ketakutan, kekacauan pikiran, kegelisahan atau penyiapan diri. Kecemasan komputer diidentifikasi sebgai technophobia. Phobia pada teknologi adalah salah satu type stress dengan teknologi menjadi salah satu penyebab kecemasan (Elhai, Levine, Dvorak, dan Hall, 2016; Saade dan Kira, 2009).

Technophobia sendiri dapat digolongkan menjadi 3 tingkatan, yaitu anxious technophobe, cognotive technophobe, unconfortable user. Anxious Technophobe merupakan reaksi kekhawatiran ketika menggunakan suatu teknologi. Tandatanda yang teridentifikasi adalah munculnya keringat ditelapak tangan, detak jantung yang keras atau sakit kepala. Cognotive Technophobe merupakan tipe kecemasan yang bersifat destruktif. Individu yang merasa tidak nyaman dengan teknologi baru terdorong untuk melakukan pengacauan. Dalam pikirannya muncul beberapa pesan negatif seperti misalnya saya akan menekan tombol yang salah, atau saya akan mengacaukan mesin ini. Unconfortable user terklasifikasi sebagai kecemasan yang tidak membahayakan (Di Giacomo, Guerra, Perilli, dan Ranieri, 2020). Kecemasan ini terjadi jika seseorang memiliki sedikit kekhawatiran dan masih muncul pernyataan negatif, tetapi secara umum tidak membutuhkan penanganan khusus.

Kecemasan terhadap komputer dapat memunculkan dua reaksi yang berbeda, yaitu: takut dan antisipasi. Takut adalah perasaan gentar dalam menghadapi sesuatu yang dianggap akan mendatangkan ancaman atau bencana. Seseorang yang merasa gelisah dengan adanya komputer cenderung akan menghindarinya. Ia menolak atau enggan untuk menggunakannya karena mereka tidak menguasai teknologi komputer. Akibatnya adalah mereka tidak bisa mendapatkan manfaat dengan kehadiran komputer. Antisipasi adalah reaksi positif mengenai hal-hal yang belum terjadi. Individu yang menerima perubahan merasakan kecemasan. Kecemasan tersebut mendorong penyesuaian mental terhadap hal-hal yang akan terjadi. Kognisinya dibangun untuk menyiapkan diri terhadap impementasi sistem informasi baru. Pada umumnya yang terjadi kemudian adalah melakukan antisipasi dengan melakukan berupaya mencari tahu, memahami, bertanya, berdiskusi dan percobaan.

Penelitian terdahulu menunjukkan terdapat pengaruh sikap takut dalam menggunakan komputer terhadap keahlian di bidang audit. Kecemasan-takut menunjukkan pengaruh yang negatif terhadap keahlian operator (Elhai et al., 2016; John, 2013; Sasongko, 2014). Berdasarkan dari penelitian-penelitian diatas bahwa terdapat asosiasi kuat antara variabel Kecemasan-takut terhadap keahlian seseorang dalam menggunakan komputer. Sehingga dapat diajukan hipotesis penelitian sebagai berikut:

H1: Kecemasan-takut memiliki pengaruh positif terhadap Keahlian Operator

Penelitian lainnya membuktikan terdapat pengaruh antisipasi terhadap keahlian (Daniel Grupe dan Nitschke, 2013; Nelson, Hodges, Hajcak, dan Shankman, 2015; Sasongko, 2014). Hasil penelitian yang sama bahwa antispasi memiliki pengaruh positif terhadap keahlian end user (Harimurti dan 
Alwan Sri Kustono: Anteseden Keahlian Operator Sistem Pengelolaan Aset Desa Di Kabupaten Situbondo

Saptantinah Puji Astuti, 2017; Hornbæk dan Hertzum, 2017). Berdasarkan dari penelitian-penelitian tersebut diajukan hipotesis penelitian sebagai berikut:

H2: Kecemasan-takut memiliki pengaruh positif terhadap Keahlian Operator.

\section{Sikap Berkomputer}

Sikap adalah perbuatan, perilaku atau gerak-gerik yang berdasarkan pada pendirian, pendapat atau keyakinan (Fiyah, Mayangky, Hadianti, dan Riana, 2019; Lee et al., 2017; Nanggala, 2020; Sanjaya, 2018). Banyak penelitian yang membuktikan bahwa faktor individu atau perilaku mempengaruhi pengadopsian teknologi informasi. Theory of reasoned action menyatakan bahwa seseorang akan menggunakan komputer jika dia dapat melihat adanya manfaat positif dari penggunaan komputer tersebut (Achim dan Kassim, 2015; Alambaigi dan Ahangari, 2016; Ilmi et al., 2020). Sikap ini akan mempengaruhi interpretasi individual. Konsekuensinya, tidak seluruh bagian organisasi menyikapi implementasi sistem informasi tersebut dengan cara pandang yang sama.

Persepsi positif terhadap komputer dapat mempengaruhi keinginan seseorang untuk lebih mempelajari teknologi komputer. Pada akhirnya upaya tersebut akan meningkatkan keahlian komputernya. Seseorang yang memiliki optimisme yang tinggi terhadap komputer akan memiliki level komptensi yang lebih tinggi (Al Kurdi, Alshurideh, Salloum, Obeidat, dan Al-dweeri, 2020; Handayani, 2010). Demikian pula sebaliknya, jika seseorang memiliki sikap negative terhadap suatu sistem informasi maka ia tidak cukup memiliki keahlian menggunakannya.

Optimisme seseorang akan muncul dengan kehadiran komputer karena merasa mampu meringankan pekerjaan dan memberikan berbagai manfaat. Komputer merupakan suatu alat yang mampu memberikan solusi dan penyelesaian pekerjaan dengan efektif.

Sikap pesimis adalah sikap percaya bahwa komputer mendominasi dan mengendalikan manusia. Seseorang yang memiliki sikap pesimis terhadap komputer maka tidak berusaha untuk meningkatkan keahliannya dalam menggunakan komputer. Individu yang memiliki tingkat pesimisme yang rendah akan memiliki keahlian komputer yang lebih tinggi.

Subjek yang memiliki sikap positif terhadap komputer lebih banyak menggunakan komputer dari pada subyek yang bersifat pesimis. Sikap ini mengarahkan perilaku individu untuk menolak atau menerima. Sikap berkomputer yang positif akan menunjukkan keahlian yang tinggi seseorang dalam berkomputer, dan sebaliknya persepsi negatif akan menurunkan keahlianya (Chen, Li, dan Li, 2011; Handayani, 2010; Nanggala, 2020; Yusuf dan Balogun, 2020; Yuwana dan Kustono, 2017). Berdasarkan dari penelitianpenelitian tersebut diajukan hipotesis penelitian sebagai berikut:

H3: Sikap berkomputer memiliki pengaruh positif terhadap keahlian operator 
Alwan Sri Kustono: Anteseden Keahlian Operator Sistem Pengelolaan Aset Desa Di Kabupaten Situbondo

\section{Pelatihan}

Pelatihan adalah proses peningkatan kompetensi untuk menyelesaikan suatu kegiatan atau pekerjaan (Salehipour dan Ah mand, 2018). Pelatihan meruapakan upaya untuk untuk memperbaiki kemampuan dan kompetensi seseorang untuk dapat meyelesaikan tugasnya. Aspek pelatihan meliputi pembelajaran, pengembangan suatu kemampuan, dan perubahan yang perilaku.

Dalam dunia kerja pelatihan merupakan salah satu faktor yang penting. Seseorang yang sudah menjalani pelatihan dapat dilihat peningkatan keahliannya dalam menyelesaikan pekerjaannya. Pekerja yang dilatih memiliki ketrampilan yang lebih tepat dan akurat. Pada dasarnya, pelaihan merupakan upaya penambahan pengetahuan baru yang bermanfaat untuk prningkatan kinerjanya (Njeru dan Omondi, 2016).

Dengan menggunakan teori perencanaan perilaku, yang menyelidiki pembedaan antara karyawan yang mengalami pelatihan dan yang belum mengalami pelatihan. Mereka juga menemukan bahwa sikap pengguna yang terlatih. Penelitian terdahulu menemukan adanya asosiasi kuat antara pelatihan dan keahlian dalam menggunakan komputer (Aggorowati, Iriawan, Suhartono, dan Gautama, 2012; Mehta, 2014; Sabar, Masitoh, dan Bachri, 2018). Berdasarkan dari penelitian-penelitian tersebut diajukan hipotesis penelitian sebagai berikut: H4: Pelatihan memiliki pengaruh terhadap keahlian operator

\section{METODE}

Data yang digunakan dalam penelitian ini adalah data primer. Teknik pemerolehan data dengan metode survey. Responden diminta untuk mengisi kuesioner yang telah disebarkan, kemudian direkapitulasi semua jawaban responden untuk dianalisis selanjutnya.

Kuesioner dibagikan secara langsung sebelum pelaksanaan pelatihan SIPADES yang diadakan pada tanggal 11-14 November 2019. Jawaban responden dikumpulkan pada saat itu untuk dianalisis lebih lanjut.

\section{Populasi dan Sampel Penelitian}

Populasi yang menjadi objek penelitian adalah operator aplikasi SIPADES di Kabupaten Situbondo. Jumlah desa di Situbondo ada 132 desa. Responden adalah seluruh operator desa, sehingga jumlahnya 132 orang. Penyampelan dengan menggunakan teknik probability sampling yakni teknik purposive sampling - accidental. Responden adalah operator SIPADES yang mengikuti pelaksanaan pelatihan SIPADES 2019.

\section{Definisi Operasional Variabel dan Pengukurannya}

Pengujian hipotesis menghubungkan antara variabel anteseden dan variabel konsekuen. Variabel independe diukur kekuatan kausalitasnya terhadap variabel dependen. Variabel-variabel tersebut adalah: 
Alwan Sri Kustono: Anteseden Keahlian Operator Sistem Pengelolaan Aset Desa Di Kabupaten Situbondo

Variabel Independent

Variabel independen adalah tipe variabel anteseden keahlian operator. Variabel independen dalam penelitian ini adalah Kecemasan-takut dan Kecemasan-anticipation, Sikap, dan Pelatihan. Adapun penjelasannya:

Kecemasan-takut. Kecemasan-takut (X1) yaitu kegelisahan terkait dengan penggunaan komputer. Pengukuran tingkat kecemasan berkomputer menggunakan instrumen CARS (Anxiety Rating Scale) yang dikembangkan oleh Heinsen et al (1987) dengan modifikasi yang diperlukan (Yuwana dan Kustono, 2017). Untuk mengukur variabel ini peneliti menggunakan indikator:

1. Perasaan takut salah dalam mengoperasikan komputer.

2. Sering membuat kesalahan.

3. Jarang menggunakan komputer setelah mengalami kesalahan.

4. Ketidaktahuan terhadap komputer membuat kinerja terasa sulit.

5. Kurang mengerti dalam menggunakan komputer.

6. Ketakutan menggunakan komputer

7. Perasaan takut salah dalam penggunaan komputer

8. Ketakutan menggunakan komputer menghambat keahlian dalam bekerja dengan komputer.

Instrumen dalam mengukur kecemasan-takut yang berupa 10 pertanyaan yang terdapat pada kuisoner dan tiap pertanyaan akan di hitung dengan menggunakan skala Likert dimulai skor 1 sangat tidak setuju (STS), skor 2 tidak setuju (TS), skor 3 ragu- ragu (R), skor 4 setuju (S) dan skor 5 sangat setuju (SS). .

Kecemasan-antisipasi. Kecemasan-antisipasi (X2) diukur dengan menggunakan instrumen CARS (Anxiety Rating Scale) yang dikembangkan oleh Heinsen et al (1987) dengan modifikasi yang diperlukan (Yuwana dan Kustono, 2017). Untuk mengukur variabel ini peneliti menggunakan indikator:

1. Belajar komputer merupakan tantangan

2. Mampu mempelajari komputer dengan baik

3. Dapat menggunakan komputer dengan baik

4. Mempelajari komputer sama dengan mempelajari beberapa hal-hal baru

5. Pemberian kesempatan belajar komputer

6. Waktu dan praktek yang cukup

7. Kesabaran dan motivasi

8. Komputer adalah hal yang penting dan mampu mengikuti perkembangan.

Instrumen dalam mengukur kecemasan-antisipasi yang berupa 7 pertanyaan yang terdapat pada kuisoner dan tiap pertanyaan akan di hitung dengan menggunakan skala linkert dimulai skor 1 sangat tidak setuju (STS), skor 2 tidak setuju (TS), skor 3 ragu-ragu (R), skor 4 setuju (S) dan skor 5 sangat setuju (SS).

Sikap. Sikap berkomputer (X3) menunjukkan bahwa perilaku ditentukan oleh apa yang orang-orang ingin lakukan. Tingkat sikap berkomputer ini diukur menggunakan instrumen komputer attitude scale (CAS) yang dikembangkan 
Alwan Sri Kustono: Anteseden Keahlian Operator Sistem Pengelolaan Aset Desa Di Kabupaten Situbondo

dalam model penerimaan teknologi dengan modifikasi yang diperlukan

(Nanggala, 2020). Untuk mengukur variabel ini, peneliti menggunakan indikator:

1. Komputer memberi era baru yang lebih cerah.

2. Penggunaan komputer meningkatkan standar hidup.

3. Penyelesaian problema dalam kehidupan menjadi lebih mudah dan cepat dengan komputer.

4. Komputer merupakan perangkat pemerolehan informasi yang efektif dan efisien.

5. Banyaknya aplikasi komputer yang belum terfikirkan.

6. Komputer telah memberi banyak manfaat.

7. Komputer dapat mengurangi pekerjaan yang membosankan.

Sikap berkomputer terdiri dari 8 pertanyaan dan tiap pertanyaan di hitung dengan menggunakan skala Likert, dimulai skor 1 sangat tidak setuju (STS), skor 2 tidak setuju (TS), skor 3 ragu-ragu (R), skor 4 setuju (S) dan skor 5 sangat setuju (SS).

\section{Pelatihan}

Pelatihan (X5). Responden ini diminta untuk mengisi berapa kali responden dalam mengikuti pelatihan SIPADES. Frekuensi berapa kalinya seseorang mengikuti pelatihan SIPADES merupakan ukuran seberapa sering responden menerima pelatihan SIPADES.

\section{Variabel Dependen}

Variabel dependen dalam penelitian adalah keahlian operator yaitu untuk mengukur persepsi responden mengenai kemampuannya menggunakan SIPADES secara menyeluruh. Dalam variabel ini pengukuran menggunakan CSE (Komputer Self Efficacy) menurut Compeau dan Higgins (1995) dengan modifikasi yang diperlukan (Yuwana dan Kustono, 2017). Variabel ini di ukur dengan menggunakan indicator:

1. Tingkat keahlian komputer operator dari aplikasi/software SIPADES.

2. Keyakinan operator dalam menyelesaikan pekerjaannya dengan menggunakan komputer.

3. Tingkat pengetahuan operator mengenai komputer

4. Tingkat kepercayaan diri operator terhadap aplikasi/software SIPADES.

Ada 32 item pertanyaan yang digunakan untuk mengukur tingkat pemakai akhir. Responden diminta memilih jawaban dalam bentuk skala Likert, dimulai skor 1 sangat tidak setuju (STS), skor 2 tidak setuju (TS), skor 3 raguragu (R), skor 4 setuju (S) dan skor 5 sangat setuju (SS).

\section{Variabel Kontrol.}

Variabel control adalah variabel yang dimasukkan dalam model untuk mengendalikan dampaknya pada variabel yang diukur. Variabel kontrol dalam penelitian ini adalah jenis kelamin (X5). Jenis kelamin diukur dengan menggunakan dummy variabel yakni pria dan wanita. 
Alwan Sri Kustono: Anteseden Keahlian Operator Sistem Pengelolaan Aset Desa Di Kabupaten Situbondo

Beberapa penelitian yang dilakukan atas pembedaan keahlian antara perempuan dan pria. Hasilnya menunjukkan bahwa pria memiliki reaksi yang lebih positif dan memiliki keahlian dalam komputer yang lebih tinggi dibandingkan wanita (Alakpodia, 2014; Gunn, 2003; Kay, 2008; Lee et al., 2017; Sorgner, Bode, dan Christiane, 2017; Wang, Stanovsky, Weihs, dan Etzioni, 2019; Wulandari, Pratomo, dan Irwanto, 2016).

\section{HASIL DAN PEMBAHASAN}

Data penelitian dikumpulkan dengan metode survey dengan teknik kuisoner yang dibagikan secara langsung kepada responden. Dari 132 desa di Kabupaten Situbondo, yang mengikutkan operator dalam pelatihan SIPADES 2019 sejumlah 111 desa. Dengan demikian kuisoner yang dibagikan, jumlah kuisoner yang dapat kembali dan dapat diolah sebesar 111 kuisoner. 21 kuisoner tidak kembali karena tidak mendapat respons. Rincian selengkapnya mengenai proses penyebaran dan pengembalian kuisoner dapat pada tabel 1 sebagai berikut:

Tabel 1. Rincian Penyebaran dan Pengembalian Kuisoner

\begin{tabular}{lc}
\hline \multicolumn{1}{c}{ Rincian } & Keterangan \\
\hline Total kuisoner yang disebarkan & 111 \\
\hline Total kuisoner yang dikembalikan & 80 \\
\hline Total kuisoner yang tidak mendapatkan respons & 21 \\
\hline Tingkat pengembalian & $72 \%$ \\
\hline
\end{tabular}

Sumber: Data primer diolah, 2019

\section{Statistik Deskriptif Variabel Penelitian}

Responden merupakan salah satu sumber data yang terpenting dalam penelitian ini. Responden memiliki karateristik atau ciri-ciri dan latar belakang yang berbeda-beda. Hal ini mempengaruhi pendapatnya tentang variabel penelitian. Responden penelitian terdiri dari 72 operator laki-laki (90\%) dan 8 orang operator perempuan $(10 \%)$.

Deskripsi variabel penelitian berguna untuk mendukung hasil analisis data yang digunakan dalam penelitian ini adalah Kecemasan-takut, Kecemasan-antisipasi, Sikap, Pelatihan dan keahlian operator SIPADES.

Tabel 2. Statistik Deskriptif

\begin{tabular}{lrrrr} 
Variabel & Minimum & Maksimum & Mean & Std.Deviation \\
\hline Kecemasan-takut & 12 & 33 & 21,70 & 5,403 \\
\hline Kecemasan-antisipasi & 20 & 45 & 36,55 & 5,496 \\
\hline Sikap & 16 & 39 & 30,95 & 5,225 \\
\hline Pelatihan & 1 & 5 & 2,22 & 1,05156 \\
\hline Keahlian & 70 & 146 & 111,5 & 20,90899 \\
\hline Valid N (listwise) & 80 & & &
\end{tabular}

Sumber: Data primer diolah (2019) 
Alwan Sri Kustono: Anteseden Keahlian Operator Sistem Pengelolaan Aset Desa Di Kabupaten Situbondo

Berdasarkan tabel 4.3 di atas menunjukkan bahwa pada variabel Kecemasan-takut (X1) jumlah jawaban responden dari 10 item pertanyaan diperoleh jawaban minimum sebesar 12 dan jawaban maksimum sebesar 33 dengan rata-rata sebesar 21,70 dan standar deviasi sebesar 5,403. Mean berjarak tidak jauh dari median. Skewness data condong ke kanan tetapi tidak terlalu tajam. Data tersebar cukup merata. Responden menunjukkan adanya kecemasan-takut pada level sedang.

Variabel Kecemasan-antisipasi (X2) jumlah jawaban responden dari 9 item pertanyaan diperoleh jawaban minimum sebesar 20 dan jawaban maksimum sebesar 45 dengan rata-rata sebesar 36,55 dan standar deviasi sebesar 5,496. Rata-rata berjarak dengan median. Hal ini menunjukkan skewness data condong ke kanan. Data tersebar merata dan mengumpul pada median. Responden terindikasi pada kondisi kecemasan-antisipasi tinggi.

Variabel Sikap Berkomputer (X3) jumlah jawaban responden minimum sebesar 16 dan jawaban maksimum sebesar 39 dengan rata-rata sebesar 30,95 dan standar deviasi sebesar 5,225. Rata-rata berjarak dengan dengan median. Hal ini menunjukkan skewness data condong ke kanan. Responden menunjukkan sikap positif berkomputer.

Rata-rata responden memperoleh pelatihan SIPADES (X1) sebanyak 2 kali dengan maksimum 5 kali dan minimum 1 kali. Seluruh operator sudah memperolah pelatihan SIPADES. Rata-rata berimpitan dengan median. Hal ini menunjukkan skewness data yang rendah. Data tersebar merata dan mengumpul pada median.

Variabel keahlian operator (Y) jumlah jawaban responden dari 32 item pertanyaan diperoleh jawaban minimum sebesar 70 dan jawaban maksimum sebesar 146 dengan rata-rata sebesar 111,5 dan standar deviasi 20,90899. Ratarata berimpitan dengan median. Hal ini menunjukkan skewness data yang rendah. Data tersebar merata dan mengumpul pada median. Responden mengindikasi memiliki keahlian menjalankan SIPADES pada level keahlian sedang.

\section{Analisa Data}

\section{Hasil Uji Validitas}

Validitas mempunyai arti sejauh mana ketepatan dan kecermatan suatu alat ukur (dalam hal ini kuisoner) melakukan fungsi ukurnya. Pengujian validitas dalam penelitian ini dilakukan dengan korelasi Pearson-validity dengan teknik product moment yaitu skor tiap item dikorelasikan dengan skor total.

Masing-masing indicator instrumen yang digunakan baik dalam variabel independen maupun variabel dependen mempunyai nilai signifikansi lebih kecil dari 0,05. Pernyataan kuesioner untuk masing-masing variabel dapat dikatakan valid. Pernyataan-pernyataan yang digunakan sebagai pengukur variabel penelitian layak digunakan. 
Alwan Sri Kustono: Anteseden Keahlian Operator Sistem Pengelolaan Aset Desa Di Kabupaten Situbondo

\section{Hasil Uji Reliabilitas}

Reliabelitas merupakan suatu kuisoner yang merupakan indikator dari variabel atau konstruk. Suatu kuisoner diakatakan reliabel atau handal jika jawaban seseorang terhadap pertanyaan adalah konsisten dari waktu ke waktu. Uji reliabilitas dilakukan dengan menggunakan koefisien Cronbach-Alpha. Jika nilai alpha suatu konstruk lebih tinggi dari 0,60, dikatakan tingkat reliabilitas pengukuran instrumen tersebut baik. Hasil pengujian reliabilitas adalah berkisar 0,863-0,976. Dapat disimpulkan bahwa semua variabel yang digunakan dalam penelitian ini adalah reliabel, karena memiliki nilai Cronbach Alpha lebih besar dari 0,60 .

\section{Pengujian Hipotesis}

Analisis regresi linier berganda digunakan untuk menguji pengaruh Kecemasan-takut, Kecemasan-antisipasi, Sikap berkomputer, Pelatihan dan Jenis Kelamin terhadap variabel keahlian operator. Berdasarkan hasil perhitungan, diperoleh hasil analisis sebagai berikut:

Tabel 3. Rekapitulasi Hasil Analisis Regresi linier berganda

\begin{tabular}{lcl}
\hline Variabel & Koef.Regresi & Sig. \\
\hline Konstanta & 17,485 & 0,468 \\
\hline Kecemasan-takut & $-0,987$ & 0,028 \\
\hline Kecemasan-antisipasi & 1,189 & 0,006 \\
\hline Sikap Berkomputer & 1,388 & 0,001 \\
\hline Pelatihan & 7,245 & 0,101 \\
\hline Jenis Kelamin & 9,589 & 0,000 \\
\hline $\mathrm{R}=0,839$ & & \\
Adjusted $R$ Square $=0,665$ & & \\
Standar Error $=13.10331$ & & \\
F sig $=0,000$ & & \\
Fhitung $=18,072$ & & \\
\hline
\end{tabular}

Sumber: Sumber: Data primer diolah (2019)

Berdasarkan hasil analisis yng bisa dilihat pada tabel 3 diperoleh hasil koefisien determinasi berganda yang disesuaikan (adjusted R2) sebesar 0,665. Hal ini berarti $66,5 \%$ perubahan operator SIPADES dipengaruhi oleh variabel Kecemasan-takut, Kecemasan-antisipasi, Sikap Berkomputer, Pelatihan dan Jenis Kelamin. Sementara itu sisanya 33,5\% disebabkan oleh faktor lain yang tidak termasuk dalam persamaan regresi.

\section{Pengujian Hipotesis}

Pengujian hipotesis dilakukan dengan menggunakan uji $\mathrm{F}$ dan dengan menggunakan uji t. Uji F untuk menguji apakah ada asosiasi regresional antara variabel keahlian operator SIPADES dengan variabel Kecemasan-takut, Kecemasan-antisipasi, Sikap Berkomputer, Pelatihan dan Jenis Kelamin. 
Alwan Sri Kustono: Anteseden Keahlian Operator Sistem Pengelolaan Aset Desa Di Kabupaten Situbondo

Tabel 3 menunjukkan hasil perhitungan statistik uji $\mathrm{F}$ sebesar 18,072 dengan probabilitas 0,000. Probabilitas jauh lebih kecil dari 0,05 yang berarti model yang dibangun yang terdiri dari variabel Kecemasan-takut, Kecemasanantisipasi, Sikap berkomputer, Pelatihan dan Jenis Kelamin memiliki pengaruh secara signifikan terhadap variabel Keahlian Operator. Model regresi dapat menjelaskan kecemasan-takut, Kecemasan-antisipasi, sikap berkomputer, Pelatihan dan Jenis Kelamin secara keseluruhan memiliki pengaruh terhadap keahlian operator.

Uji $\mathrm{t}$ dimaksudkan untuk mengetahui pengaruh masing-masing variabel independen terhadap variabel dependen. Masing-masing variabel independen dikatakan mempunyai pengaruh yang signifikan (nyata) apabila probabilitas $<5 \%(\alpha)$.

Hasil perhitungan uji $\mathrm{t}$ dapat dilihat pada tabel 3. Berdasarkan hasil pengujian dapat diketahui besarnya pengaruh masing-masing variabel independen terhadap variabel dependen sebagai berikut:

1. Pengaruh variabel Kecemasan-takut (X1) terhadap Keahlian Operator (Y).

Tabel 3 menunjukkan bahwa tingkat probabilitas $<a$ yaitu $0,028<0,05$. Tingkat probabilitasnya lebih kecil dari 5\% maka $\mathrm{H} 0$ ditolak, berarti variabel Kecemasan-takut (X1) mempunyai pengaruh signifikan secara statistik terhadap keahlian operator (Y). Hipotesis yang menyatakan Kecemasantakut memiliki pengaruh negatif terhadap keahlian operator diterima.

2. Pengaruh variabel Kecemasan-antisipasi (X2) terhadap Keahlian Operator (Y).

Tabel 3 menunjukkan bahwa tingkat probabilitas $<$ a yaitu $0,006<0,05$. Tingkat probabilitasnya lebih kecil dari 5\% maka H0 ditolak. Variabel Kecemasan-antisipasi (X2) mempunyai pengaruh signifikan secara statistik terhadap keahlian operator (Y). Hipotesis yang menyatakan Kecemasanantisipasi memiliki pengaruh positif terhadap keahlian operator diterima.

3. Pengaruh variabel Sikap berkomputer $(\mathrm{X} 3)$ terhadap Keahlian Operator $(\mathrm{Y})$.

Tabel 3 menunjukkan bahwa tingkat probabilitas <a yaitu 0,001<0,05. Tingkat probabilitasnya lebih kecil dari 5\% maka H0 ditolak. Variabel sikap berkomputer (X3) mempunyai pengaruh signifikan secara statistik terhadap keahlian operator (Y). Hipotesis yang menyatakan Sikap Berkomputer memiliki pengaruh positif terhadap Keahlian Operator diterima.

4. Pengaruh variabel Pelatihan (X4) terhadap Keahlian Operator (Y).

Tabel 3 menunjukkan bahwa tingkat probabilitas <a yaitu 0,000<0,05. Tingkat probabilitasnya lebih kecil dari 5\% maka H0 ditolak. Variabel Pelatihan (X4) mempunyai pengaruh signifikan secara statistik terhadap keahlian operator $(\mathrm{Y})$. Hipotesis yang menyatakan Pelatihan memiliki pengaruh positif terhadap Keahlian Operator terbukti kebenarannya (H5 diterima).

5. Pengaruh variabel Jenis Kelamin (X5) terhadap Keahlian Operator (Y). 
Alwan Sri Kustono: Anteseden Keahlian Operator Sistem Pengelolaan Aset Desa Di Kabupaten Situbondo

Tabel 3 menunjukkan bahwa tingkat probabilitas $>a$ yaitu $0,101>0,05$. Tingkat probabilitasnya lebih besar dari 5\% maka H0 diterima. Variabel Jenis Kelamin (X5) tidak mempunyai pengaruh secara statistik terhadap Keahlian Operator $(\mathrm{Y})$.

\section{Pembahasan}

\section{Pengaruh Kecemasan-takut terhadap Keahlian Operator.}

Hasil uji regresi menunjukkan variabel kecemasan-takut memiliki pengaruh negatif dan signifikan terhadap keahlian operator SIPADES dengan koefisien -0,987. Hal ini berarti dengan semakin tingginya rasa takut yang dimiliki pegawai terhadap komputer maka keahlian karyawan dalam menggunakan komputer menurun, begitu juga sebaliknya. Hal ini berarti faktor kecemasan-takut yang diukur melalui perasaan rasa takut salah dalam mengoperasikan aplikasi, sering adanya kesalahan pada saat bekerja dengan aplikasi, jarangnya menggunakan aplikasi setelah mengalami kesalahan, ketidaktahuan terhadap aplikasi membuat kinerja terasa sulit, kurang mengerti dalam menggunakan aplikasi, ketakutan menggunakan aplikasi, perasaan takut salah dalam penggunaan aplikasi, serta ketakutan menggunakan aplikasi akan menghambat keahlian dalam bekerja dengan aplikasi merupakan suatu faktor yang akan mempengaruhi penurunan keahlian operator SIPADES.

Operator SIPADES dituntut mampu menggunakan dan menerapkan fiturfitur aplikasi SIPADES seperti pencatatan, pelaporan dan pendokumentasian. Semuanya yang awalnya manual dan kemudian beralih menjadi terkomputerisasi. Perkembangan teknologi ini menuntut staff harus memiliki kemampuan dan keahlian untuk menggunakan aplikasi tersebut yang terdapat pada komputer.

Peranan kinerja SIPADES tidak lepas dari komputer, dalam pekerjaan tersebut komputer digunakan sebagai alat atau suatu sarana yang digunakan untuk menyelesaikan pekerjaan yang berasosiasi dengan SIPADES. Pada dasarnya SIPADES merupakan suatu sistem informasi. SIPADES digunakan sebagai suatu sarana yang digunakan sebagai alat bantu dalam menunjang kegiatan dalam bidang keuangan, akuntansi dan manajerial pengelolaan asset desa.

Seorang operator dituntut untuk menguasai aplikasi SIPADES secara terkomputerisasi, Mereka harus memiliki kemampuan dalam bekerja. Kemampuan tersebut tergantung pada masing-masing individu. Salah satu yang mempengaruhi adalah rasa takut terhadap komputer. Kondisi dimana seseorang merasa gelisah dengan adanya komputer karena mereka belum banyak menguasai teknologi komputer. Semakin tinggi rasa takut yang ada pada seseorang berakibat pada penurunan keahlian operator. Semakin cemas pegawai terhadap teknologi komputer mengakibatkan penghindaran atau penolakan dalam mempelajari maupun menggunakkan komputer. Semakin takut seseorang dalam menggunakan komputer maka keahlian seseorang tersebut 
Alwan Sri Kustono: Anteseden Keahlian Operator Sistem Pengelolaan Aset Desa Di Kabupaten Situbondo

dalam menggunakan komputer menurun. Hasil penelitian ini konsisten dengan penelitian lainnya (Elhai et al., 2016; John, 2013; Sasongko, 2014) yang menyatakan bahwa kecemasan-takut memiliki pengaruh negatif signifikan terhadap keahlian operator.

\section{Pengaruh Kecemasan-antisipasi terhadap Keahlian Operator}

Hasil uji regresi mununjukkan variabel Kecemasan-antisipasi memiliki pengaruh positif dan statistik signifikan terhadap keahlian operator dengan koefisien 1,189. Hal ini berarti dengan semakin tingginya tindakan antisipasi yang dimiliki pegawai terhadap penggunaan komputer, maka keahlian operator semakin meningkat. Faktor Kecemasan-antisipasi adalah hal yang penting dan merupakan faktor yang mempengaruhi keahlian operator.

Antisipasi merupakan perhitungan hal-hal yang belum terjadi, bayangan, ramalan atau penyesuaian mental terhadap hal-hal yang akan terjadi. Kecemasan tersebut memunculkan dorongan untuk antisipasi. Individu yang tertantang berusaha meningkatkan kompetensinya dengan mempelajari dan mencoba-coba.

SIPADES digunakan sebagai suatu sarana untuk mencatat dan mengelola asset desa dengan cepat, akurat dan tepat. Dengan aplikasi berbasis komputer, operator dituntut menggunakan komputer untuk menjalankan aplikasi tersebut.

Kesulitan dengan penggunaan komputer hal mendorong seseorang untuk melakukan tindakan antisipatif. Tindakan antisipatif dapat berupa membaca buku, belajar dari rekan sejawat atau orang yang ahli, berani mencoba dan berusaha untuk menggunakan aplikasi. Tindakan antisipatif tersebut dapat mengatasi kesulitan dalam penggunaan aplikasi dan masalah-masalah yang timbul dalam berbagai kasus.

Tindakan antisipatif berdampak positif terhadap keahlian operator. Seseorang yang memiliki antisipasi yang tinggi semakin meningkatkan keahliannya dalam menggunakan komputer. Ia memiliki keinginan untuk mempelajari hal-hal yang selama ini tidak dikuasainya sehingga dapat meningkatkan keahlian operator. Semakin tinggi antisipasi seseorang dalam menggunakkan komputer maka keahliannya dalam menggunakkan aplikasi semakin meningkat. Bersamaan dengan itu, kecemasannya dalam menjalankan aplikasi semakin menurun. Hasil penelitian ini konsisten dengan penelitian terdahulu (Daniel Grupe dan Nitschke, 2013; Nelson et al., 2015; Sasongko, 2014) yang menyatakan bahwa Kecemasan-antisipasi memiliki pengaruh positif signifikan terhadap keahlian operator.

\section{Pengaruh Sikap Berkomputer terhadap Keahlian Operator}

Hasil uji regresi menunjukkan variabel sikap berkomputer memiliki pengaruh positif secara statistik signifikan terhadap variabel keahlian operator dengan koefisien 1,388. Hal ini berarti, semakin tinggi sikap optimis seseorang dalam menggunakan SIPADES maka keahlian operator semakin meningkat. 
Alwan Sri Kustono: Anteseden Keahlian Operator Sistem Pengelolaan Aset Desa Di Kabupaten Situbondo

Sikap berkomputer yang diukur melalui penggunaan SIPADES membuat pekerjaan lebih efisien, ekonomis, dan efektif dalam penatalaksanaan asset desa.

Aplikasi komputer digunakan untuk mengolah data dan informasi dengan lebih cepat dan murah. Sikap positif terhadap aplikasi SIPADES yang telah memberi banyak manfaat dan kemudahan merupakan faktor yang menentukan perubahan tingkat keahlian operator SIPADES.

SIPADES merupakan salah satu perangkat dalam mewujudkan tata kelola desa yang Komputer adalah sarana yang sangat vital dalam menunjang kinerja pengelolaan asset desa. SIPADES memampukan mengolah berbagai data asset di desa dengan tertib sehingga menunjang dan mempermudah pengelolaan pemerintahan desa.

Operator yang senang dengan aplikasi berusaha memahami dan mempelajari apa yang disenanginya. Jika operator merasakan manfaat penggunaan aplikasi SIPADES dan timbul rasa percaya pada dirinya bahwa aplikasi sangat membantu dan memberikan manfaat pada dirinya. Dan hal tersebut menimbulkan sikap optimisme operator terhadap penggunaan aplikasi SIPADES. Operator yang percaya bahwa aplikasi membantu dirinya dalam menyelesaikan pekerjaan, dia akan senang mempelajari aplikasi SIPADES dan mengikuti perkembangan aplikasi SIPADES. Semakin optimis operator dalam menggunakan aplikasi meningkatkan keahliannya. Perasaan pesimis pada operator tersebut akan semakin berkurang. Hasil penelitian ini mendukung temuan sikap memiliki pengaruh signifikan terhadap keahlian operator (Handayani, 2010; Chen, Li and Li, 2011; Yuwana and Kustono, 2017; Nanggala, 2020; Yusuf and Balogun, 2020).

\section{Pengaruh Pelatihan terhadap Keahlian Operator}

Hasil uji regresi pada tabel 3 menunjukkan variabel pelatihan memiliki pengaruh positif dan signifikan secara statistik terhadap keahlian operator dengan koefisien 9,549. Hal ini berarti dengan semakin seringnya pelatihan yang sudah dilalui seseorang maka keahlian operator tersebut akan semakin meningkat.

Pelatihan adalah proses melatih suatu kegiatan atau pekerjaan. Pelatihan adalah setiap usaha untuk memperbaiki performansi pekerja pada suatu pekerjaan tertentu yang menjadi tanggung jawabnya. Pelatihan mencakup pembelajaran serta pengembangan suatu kemampuan dalam pekerjaanya. Pelatihan juga mencangkup perubahan perilaku yang diakibatkan adanya pemahaman dan praktik.

Seseorang yang sudah mengikuti pelatihan dapat meningkat kompetensinya. Ia memperoleh tambahan pengetahuan dan ketrampilan yang diperoleh lewat keterlibatan selama beberapa periode tertentu. Seseorang yang terlatih dibidang tertentu biasanya lebih mampu dalam menjalahkan pekerjaanya secara maksimal. 
Alwan Sri Kustono: Anteseden Keahlian Operator Sistem Pengelolaan Aset Desa Di Kabupaten Situbondo

Hasil ini sesuai dengan penelitian terdahulu (Aggorowati et al., 2012; Mehta, 2014; Sabar et al., 2018). Pelatihan SIPADES dilakukan adalah untuk meningkatkan suatu kemampuan dan keahlian mereka sebagai operator SIPADES. Seorang operator SIPADES diharuskan memiliki kemahiran yang berasosiasi dengan aplikasi. Pelatihan dalam menjalankan SIPADES yang mendorong peningkatan kinerja secara maksimal sehingga secara keseluruhan berkontribusi terhadap kinerja pemerintahan desa yang akuntabel dan transaparan.

Operator yang sudah mengikuti pelatihan meningkat keahlian mengoperasikan aplikasi. Semakin seseorang sering mengikuti pelatihan SIPADES, ia akan mahir dan mampu menjalankan aplikasi dengan maksimal. Operator yang terlatih memiliki kompetensi menjalankan SIPADES dengan lebih baik.

\section{Pengaruh Jenis Kelamin terhadap Keahlian Operator.}

Hasil uji regresi pada tabel 3 menunjukkan variabel jenis kelamin memiliki pengaruh positif namun tidak signifikan secara statistik terhadap keahlian operator dengan koefisien 7,245. Hal ini berarti faktor jenis kelamin bukan menjadi faktor yang menentukkan keahlian operator. Dari responden yang diteliti tingkat keahlian antara laki-laki dan perempuan tidak jauh berbeda, selain itu kemampuan antara laki-laki dan perempuan hampir setara dalam hal menggunakkan komputer, kemampuan antara laki-laki dan perempuan sama baiknya. Hal ini dibuktikan dengan tidak adanya perbedaan dalam hal penempatan dan suatu porsi dalam bekerja, dalam pekerjaannya antara laki-laki dan perempuan mempunyai porsi yang sama.

Operator memiliki suatu karakter sifat dan kemampuan dalam bekerja yang berbeda-beda, hal tersebut ditunjukkan dengan adanya perbedaan jenis kelamin. Laki-laki dan perempuan memiliki suatu sifat yang berbeda dan hal tersebut dapat mempengaruhi kehidupan mereka dalam bekerja. Pada Pemerintah Daerah Jember mekanisme operator dalam bekerja tanpa melihat perbedaan jenis kelamin. Operator dituntut dapat menjalankan aplikasi secara maksimal. Peran operator SIPADES sendiri sangat vital dalam pencatatan, pengadministrasian, dan pelaporan kekayaan desa. Operator harus mampu memahami kinerja aplikasi secara maksimal.

\section{KESIMPULAN}

Pada penelitian ini bertujuan untuk memberikan bukti empiris bahwa terdapat pengaruh Kecemasan-takut, Kecemasan-antisipasi, Sikap Berkomputer, Pelatihan dan Jenis Kelamin terhadap keahlian operator dalam menjalankan SIPADES. Hasil penelitien menunjukkan bahwa Kecemasan-takut dan Kecemasan-antisipasi, sikap berkomputer, dan pelatihan memiliki pengaruh terhadap keahlian operator SIPADES. 
Alwan Sri Kustono: Anteseden Keahlian Operator Sistem Pengelolaan Aset Desa Di Kabupaten Situbondo

1. Hasil pengujian hipotesis pertama menunjukkan bahwa kecemasan-takut memiliki pengaruh negatif secara statistik signifikan terhadap keahlian operator. Semakin tinggi ketakutan operator desa tersebut terhadap komputer akan semakin rendah pula kemampuan operator desa tersebut dalam menggunakkan SIPADES.

2. Hasil pengujian hipotesis kedua menunjukkan bahwa Kecemasan-antisipasi memiliki pengaruh positif secara statistik signifikan terhadap keahlian operator. Apabila seorang operator desa mempunyai suatu antisipasi yang tinggi terhadap kewajiban menerapkan SIPADES maka akan mengurangi tingkat kecemasan operator desa tersebut, sehingga akan meningkatkan keahlian operator seseorang operator desa.

3. Hasil pengujian hipotesis ketiga menunjukkan bahwa sikap berkomputer memiliki pengaruh positif secara statistik signifikan terhadap keahlian operator yaitu operator desa. Seorang operator desa yang memiliki sikap berkomputer yang tinggi maka akan meningkatkan keahlian operator desa tersebut dalam menggunakan SIPADES.

4. Hasil pengujian hipotesis keempat, menunjukkan variabel pelatihan memiliki pengaruh positif signifikan terhadap keahlian operator yaitu operator desa. Keahlian seseorang dalam menggunakan SIPADES dapat meningkat melalui adanya proses pelatihan.

Penelitian ini memiliki keterbatasan yaitu sampel diambil dengan metode probability. Tidak semua operator memiliki kesempatan yang sama untuk menjadi sampel. Hal ini disebabkan dengan penyebaran kuesioner hanya pada saat pelatihan. Penelitian mendatang perlu mempertimbangkan penyebaran secara langsung ke desa-desa dimana operator bekerja.

Bagi penelitian selanjutnya perlu mengembangkan perspektif dengan mencari dan menemukan variabel-variabel lain yang diteliti yang dapat menjelaskan dengan lebih baik mengenai keahlian operator dalam menggunakan SIPADES seperti dukungan organisasi, keyakinan diri, perceived enjoyment dengan basis model penerimaan teknologi 3 dan model penggunaan mikro komputer.

Sample penelitian adalah finit jumlahnya. Penelitian selanjutnya dapat menggunakan metoda mixed method, sehingga kualitas informasi meningkat. Hasil penelitian dapat lebih komprehensif dan agregatif.

\section{DAFTAR PUSTAKA}

Achim, N., dan Kassim, A. Al. (2015). Computer Usage: The Impact of Computer Anxiety and Computer Self-efficacy. Procedia - Social and Behavioral Sciences, 172, 701-708. https://doi.org/10.1016/j.sbspro.2015.01.422

Aggorowati, M. A., Iriawan, N., Suhartono, S., dan Gautama, H. (2012). Restructuring and Expanding Technology Acceptance Model Structural 
Alwan Sri Kustono: Anteseden Keahlian Operator Sistem Pengelolaan Aset Desa Di Kabupaten Situbondo

Equation Model and Bayesian Approach. American Journal of Applied

Sciences, 9(4), 496-504. https:// doi.org/10.3844/ajassp.2012.496.504

Al Kurdi, B., Alshurideh, M., Salloum, S. A., Obeidat, Z. M., dan Al-dweeri, R. M. (2020). An Empirical Investigation into Examination of Factors Influencing University Students' Behavior towards Elearning Acceptance Using SEM Approach. International Journal of Interactive Mobile Technologies (IJIM), 14(02), 19. https:// doi.org/10.3991/ijim.v14i02.11115

Alakpodia, O. N. (2014). Gender Differences in Computer Use Skill Among Students of School of Health Technology, Ufuoma, Delta State. International Journal of Digital Library Services, 1142(1998), 1-11.

Alambaigi, A., dan Ahangari, I. (2016). Technology Acceptance Model (TAM) As a Predictor Model for Explaining Agricultural Experts Behavior in Acceptance of ICT. International Journal of Agricultural Management and Development, 6(2), 235-247.

Chen, S. C., Li, S.-H., dan Li, C.-Y. (2011). Recent Related Research in Technology Acceptance Model: A Literature Review. Australian Journal of Business and Management Research, 1(9), 124-127. https://doi.org/10.16194/j.cnki.311059/g4.2011.07.016

Di Giacomo, D., Guerra, F., Perilli, E., dan Ranieri, J. (2020). Technophobia as Emerging Risk Factor In Aging: Investigation On Computer Anxiety Dimension. Health Psychology Research, 8(1), 1-4. https:// doi.org/10.4081/hpr.2020.8207

Elhai, J. D., Levine, J. C., Dvorak, R. D., dan Hall, B. J. (2016). Fear of Missing Out, Need For Touch, Anxiety and depression are Related To Problematic Smartphone Use. Computers in Human Behavior, 63, 509-516. https:// doi.org/10.1016/j.chb.2016.05.079

Firmansyah, A. (2018). Pengelolaan Aset Desa di Kabupaten Tangerang. Jurnal Ilmiah Akuntansi Kesatuan, 6(1), 001-008. https:// doi.org/10.37641/jiakes.v6i1.58

Fiyah, N., Mayangky, N. A., Hadianti, S., dan Riana, D. (2019). Analisis Technology Acceptance Model pada Aplikasi Platform Perdagangan Elektronik Di Kalangan Mahasiswa. Jurnal Teknik Informatika, 12(1), 59-68. https://doi.org/10.15408/jti.v12i1.10507

Grupe, D, dan Nitschke, J. (2013). Uncertainty and Anticipation in Anxiety. Nat Rev Neurosci, 14(7), 488-501. https:/ / doi.org/10.1038/jid.2014.371

Grupe, Daniel, dan Nitschke, J. (2013). Uncertainty and Anticipation in Anxiety: An Integrated Neurobiological and Psychological Perspective. Nature Reviews. Neuroscience, 14, 488-501. https:// doi.org/10.1038/nrn3524 
Alwan Sri Kustono: Anteseden Keahlian Operator Sistem Pengelolaan Aset Desa Di Kabupaten Situbondo

Gunn, C. (2003). Dominant or different: Gender Issues In Computer Supported Learning. JALN Volume, 7. https:// doi.org/10.24059/olj.v7i1.1860

Handayani, R. (2010). Analisis Faktor-Faktor yang Mempengaruhi Penerimaan Penggunaan Personal Computer dengan Teknology Acceptance Model. Riset Manajemen Dan Akuntansi, 1(2010), 55-66.

Harimurti, F., dan Saptantinah Puji Astuti, D. (2017). Pengaruh Computer Anxiety Terhadap Keahlian Pemakai Komputer dengan Internal Locus of Control sebagai Variabel Moderasi. Jurnal Ilmiah Akuntansi Dan Bisnis, 91. https://doi.org/10.24843/jiab.2016.v11.i02.p04

Hoque, M. E., dan Shah, N. U. (2018). Enterprise resource planning system integration and its effects on relationship between lean practices and organisational performances : A conceptual framework. 7(4), 1449-1461.

Hornbæk, K., dan Hertzum, M. (2017). Technology acceptance and user experience: A review of the experiential component in HCI. ACM Transactions on Computer-Human Interaction, 24(5). https:// doi.org/10.1145/3127358

Ilmi, M., Setyo Liyundira, F., Rachmawati, A., Juliasari, D., dan Habsari, P. (2020). Perkembangan dan Penerapan Theory Of Acceptance Model (TAM) Di Indonesia. Relasi: Jurnal Ekonomi, 16(2), 436-458. https:// doi.org/10.31967/ relasi.v16i2.371

Irwandi, I., Andrizal, A., dan Putra, T. D. (2019). Kebijakan Pemerintah Desa dalam Pengelolaan Dana Desa di Kabupaten Muaro Jambi. Jurnal Sains Sosio Humaniora, 3(2), 221-227. https://doi.org/10.22437/jssh.v3i2.8424

John, S. P. (2013). Influence of Computer Self-Efficacy on Information Technology Adoption. Internation Journal of Information Technology, 19(1), 1-13.

Kay, R. (2008). Exploring Gender Differences in Computer-Related Behaviour: Past, Present, and Future. In Social Information Technology: Connecting Society and Cultural Issues (pp. 12-30). https://doi.org/10.4018/978-1-59904-7744.ch002

Kumar, Sivashanmugam, dan Venkataraman. (2017). Intention To Use Mobile Wallet: Extension of TAM Model. International Journal of Current Engineering and Scientific Research, 4(12), 2393-8374.

Kustono, A. S., dan Valencia, Z. G. (2017). How The Effectiveness Knowledge Sharing Affect Enterprise Resource Planning System Case in East JavaIndonesia. Advanced Science Letters, 23(5), 4295-4297. https:// doi.org/10.1166/asl.2017.8263 
Alwan Sri Kustono: Anteseden Keahlian Operator Sistem Pengelolaan Aset Desa Di Kabupaten Situbondo

LaPlant, K. (2015). Why Computer Hardware Skills Are Important in Achieving Academic Success and Improving Retention. Business and Information Technology, 3. Retrieved from www.hennepintech.edu

Lee, Y., Wang, S., Vorlicek M, Surendran, P., Schepard, A. I., Emery, R. E., (2017). Technology Acceptance Model. Business Management and Strategy, 3(1), 121. https://doi.org/10.1007/s10661-014-3885-4

Mannila, L., Nordén, L. Å., dan Pears, A. (2018). Digital competence, Teacher Self-Efficacy and Training Needs. ICER 2018 - Proceedings of the 2018 ACM Conference on International Computing Education Research, 78-85. https:// doi.org/10.1145/3230977.3230993

Mastuti, E., dan Handoyo, S. (2019). Computer competency, Test Anxiety, dan Perceived Ease of Use Profile Exploration of High School Students During Computer-Based Testing. North American Journal of Psychology, 21(1), 169172.

Mehta, A. (2014). Technology Acceptance Of E-Learning Within A Blended Vocational Course in West Africa. Proceedings of the International Conference E-Learning 2014 - Part of the Multi Conference on Computer Science and Information Systems, MCCSIS 2014, (Ajzen 1980), 324-328.

Nanggala, A. Y. A. (2020). Use of Fintech for Payment: Approach to Technology Acceptance Model Modified. Journal of Contemporary Information Technology, Management, and Accounting, 1(1), 1-8.

Nelson, B. D., Hodges, A., Hajcak, G., dan Shankman, S. A. (2015). Anxiety Sensitivity And The Anticipation Of Predictable And Unpredictable Threat: Evidence From The Startle Response And Event-Related Potentials. Journal of Anxiety Disorders, 33, 62-71. https:/ / doi.org/10.1016/j.janxdis.2015.05.003

Njeru, M. N., dan Omondi, M. (2016). Relationship between Total Quality Management and Employee Performance in Public Universities in Kenya: A Case Study of Kirinyaga University College. The Strategic Journal of Business and Change Management, 3(2(21)), 455-483.

Nugraha, A., dan Laksito, H. (2014). Anteseden Penerimaan Teknologi Informasi Dalam Profesi Audit Internal Dengan Menggunakan Technology Acceptance Model (Studi Empiris pada Bank Perkreditan Rakyat di Jawa Tengah). 3(2), 185199.

Pemdes, D. B. (2018). Modul Pelatihan Sistem Aset Desa. Kementerian Dalam Negeri.

Pujanira, P., dan Taman, A. (2017). Pengaruh Kompetensi Sumber Daya Manusia, Penerapan Standar Akuntansi Pemerintahan, dan Penerapan Sistem Akuntansi Keuangan Daerah Terhadap Kualitas Laporan Keuangan 
Alwan Sri Kustono: Anteseden Keahlian Operator Sistem Pengelolaan Aset Desa Di Kabupaten Situbondo

Pemerintah Daerah Provinsi DIY. Nominal, Barometer Riset Akuntansi Dan Manajemen, 6(2). https:// doi.org/10.21831/nominal.v6i2.16643

Saade, R., dan Kira, D. (2009). Computer Anxiety in E-Learning: The Effect of Computer Self-Efficacy. Proceedings of the 2009 InSITE Conference, 8. https:// doi.org/10.28945/3386

Sabar, S., Masitoh, S., dan Bachri, B. (2018). Development of Computer Learning Materials To Improve Spreadsheet Skills for Training Participants. https:// doi.org/10.2991/icei-18.2018.107

Salehipour, A., dan Ah mand, A. (2018). The Impact of Organizational Culture and Performance Work System on Employees' Performance. International Business Research, 11(6), 199. https:// doi.org/10.5539/ibr.v11n6p199

Sanjaya, E. A. (2018). Pengaruh Technology Acceptance Model dan End User Computing Satisfaction terhadap Penerimaan Pengguna Akhir Electronic Data Processing dengan Sikap Sebagai Variabel Mediasi (Studi Kasus di Anugerah Fabric Store Yogyakarta). Thesis. Universitas Sanata Dharma Yogyakarta.

Sasongko, W. P. (2014). Pengaruh Computer self-efficacy, Computer Fear Dan Computer Anticipation terhadap Attitude Toward Computer. Skripsi. Perbanas Surabaya.

Sorgner, A., Bode, E., dan Christiane, K.-B. (2017). The Effects of Digitalization on Gender Equality in the G20 Economies. G20 Insights, (July), 1-167.

Sutaryo, S., dan Nuwandari, I. (2016). Praktik Pengelolaan Aset Desa Di Pemerintahan Desa Provinsi Jawa Tengah. AKRUAL, 7(2), 140-162.

Wang, L. L., Stanovsky, G., Weihs, L., dan Etzioni, O. (2019). Gender Trends in Computer Science Authorship. (June 2018), 1-9. Retrieved from http://arxiv.org/abs/1906.07883

Wulandari, Y. M., Pratomo, S. A., dan Irwanto, W. S. (2016). Pengaruh Persepsi Kebermanfaatan, Kemudahan Penggunaan, Kepuasan Pengguna, Keamanan Dan Kerahasiaan Dan Kenyamanan Wajib Pajak Terhadap Penggunaan E-Filing (Studi Kasus pada Wajib Pajak Orang Pribadi di Kantor Pelayanan Pajak Pratama Klaten). Kiat BISNIS, 6(4). https:// doi.org/10.1016/j.pnpbp.2012.06.012

Yusuf, M. O., dan Balogun, M. R. (2020). Student-Teachers' Competence and Attitude towards Information and Communication Technology: A Case Study in a Nigerian University. Contemporary Educational Technology, 2(1), 18-36. https:// doi.org/10.30935/cedtech/6041 
Alwan Sri Kustono: Anteseden Keahlian Operator Sistem Pengelolaan Aset Desa Di Kabupaten Situbondo

Yuwana, A. M., dan Kustono, A. S. (2017). Why is User"s Expertise Important for Implementation of Regional Asset Information Systems: Case in Indonesia. International Journal of Science and Research (IJSR), 6(7), 377-379. https:// doi.org/10.21275/art20175027 